\title{
Musculoskeletal pain and ergonomic aspects of dentistry*
}

\section{Dores osteomusculares e aspectos ergonômicos na prática odontológica}

\author{
Artênio José Ísper Garbin ${ }^{1}$, Cléa Adas Saliba Garbin , Renato Moreira Arcieri ${ }^{1}$, Tânia Adas Saliba Rovida ${ }^{1}$, Ana Carolina da Graça \\ Fagundes Freire ${ }^{1}$
}

${ }^{*}$ Received from School of Dentistry of Araçatuba, Paulista State University, Araçatuba, SP, Brazil.

DOI 10.5935/1806-0013.20150018

\section{ABSTRACT}

BACKGROUND AND OBJECTIVES: Dentists are considered professionals highly vulnerable to occupational problems and such injuries are sometimes caused by adopted postures and repetitive efforts during their work. This study aimed at checking the prevalence of musculoskeletal pain and to observe whether the work of dentists acting in both public and private sectors was carried out ergonomically.

METHODS: This is a cross-sectional, descriptive and observational study with dentists $(n=80)$. A self-applicable questionnaire was used to check the frequency of musculoskeletal pain and occupational injuries, as well as to record labor activities, practice of physical activity and their frequencies. Professionals were observed while carrying out dental assistance based on recommendations of the document "Adopting a healthy sitting working posture during patient treatment", which is part of the International Standards Organization standardization 106/SC 6 N 411 from 2006.

RESULTS:There has been job-related pain in at least $65.67 \%$ of dentists. The number of individuals adopting incorrect and inadequate positions during assistance was high, such as: head rotation $(73.13 \%)$; spine rotation $(47.76 \%)$ and legs angle less than $90^{\circ}(91.04 \%)$. Medical leaves related to occupational injuries were found in a greater proportion among public service professionals (64\%).

CONCLUSION:There has been high prevalence of musculoskeletal pain related to inadequate postures adopted during clinical assistance and to long working hours without pause.

Keywords: Dentistry, Epidemiology, Human engineering, Musculoskeletal pain, Pain.

\footnotetext{
1. Paulista State University, School of Dentistry of Araçatuba, Araçatuba, SP, Brazil.

Submitted in November 09, 2014.

Accepted for publication in April 15, 2015.

Conflict of interests: none - Sponsoring sources: FAPESP - Foundation for Research Support of the State of São Paulo.

Correspondence to:

Ana Carolina da Graça Fagundes Freire

Faculdade de Odontologia de Araçatuba-UNESP

Departamento de Odontologia Infantil e Social

Rua José Bonifácio, 1193

16011-205 Araçatuba, SP, Brasil.

E-mail: acgfagundes@yahoo.com.br

(C) Sociedade Brasileira para o Estudo da Dor
}

\section{RESUMO}

JUSTIFICATIVA E OBJETIVOS: O cirurgião-dentista é apontado como um profissional muito vulnerável a problemas ocupacionais e essas lesóesàs vezes ocorrem devido a posturas adotadas e esforços repetitivos durante seu trabalho. O objetivo deste estudo foi verificar a prevalência de dores osteomusculares e observar se o trabalho dos cirurgiōes-dentistas que atuam no setor público e privado foi realizado de forma ergonômica.

MÉTODOS: Trata-se de um estudo com desenho transversal, descritivo e observacional, com cirurgióes-dentistas $(n=80)$. Com um questionário autoaplicável verificou-se a frequência de dores musculoesqueléticas e lesôes ocupacionais, bem como o registro das atividades laborais, prática de atividade física e suas frequências. Os profissionais foram observados enquanto realizavam o atendimento odontológico baseado nas recomendaçóes contidas no documento "Adopting a healthy sitting working posture during patient treatment", que é parte da normatização da International Standards Organization, 106/SC 6 N 411 de 2006. RESULTADOS: Houve experiência de dor relacionada ao trabalho em pelo menos $65,67 \%$ dos cirurgióes-dentistas. O número de indivíduos que adotam posiçóes incorretas e inadequadas durante os atendimentos foi elevado, tais como: rotação da cabeça (73,13\%); rotação da coluna $(47,76 \%)$ e angulação das pernas menor que $90^{\circ}(91,04 \%)$. Afastamentos relacionados a lesóes ocupacionais foram encontrados numa proporção maior entre os profissionais do serviço público (64\%).

CONCLUSÁO: Houve alta prevalência de dores osteomusculares relacionadas com as posturas inadequadas adotadas durante os atendimentos clínicos e a longas jornadas de trabalho sem pausas.

Descritores: Dor, Dor musculoesquelética, Engenharia humana, Epidemiologia, Odontologia.

\section{INTRODUCTION}

Dentistry working market is becoming increasingly competitive and this is influencing the daily life of dentists, bringing changes to their professional activities and requiring more working hours. These daily difficulties are exposing dentists to increasingly stressing situations ${ }^{1}$. It is possible that this whole labor transformation process favors adverse physical and psycho-social conditions, among them the appearance or worsening of pain, thus bringing changes to the quality of life (QL) of such professionals ${ }^{2,3}$. It may also generate high 
stress levels, contributing to make many workers with 40 to 50 years of age unable to respond to the requirements of tasks proposed to them ${ }^{4}$. Since stress has several causes, it is not possible to establish a single way to prevent it or fight it. Associated to this, a certain working posture, maintained for a long time, may lead to continuous stress of most required muscles and may generate circulatory and metabolic disorders, in addition to causing pain or muscle discomfort ${ }^{5}$. The origin of musculoskeletal injuries is in general related to labor activities requiring excessive strength with hands, inadequate upper limbs (UULL) postures, repetitiveness of a same movement, mechanical compression of UULL structures and neighbor regions (shoulders, arms and hands) and not enough time to carry out a certain job ${ }^{6}$. In this sense, dentists are exposed to stress, anxiety and excessive physical effort $^{2,7}$.

The prevalence of musculoskeletal disorders is higher than any other occupational disease among dentists and this is due to the fact that such professionals work for long periods in inflexible and prolonged static postures, carrying out delicate and accurate procedures ${ }^{8-10}$. To meet the specifications of the profession, dentists adopt a kyphotic posture, bending and twisting the head to adjust their field of vision, with lumbar rotations and UULL flexion ${ }^{11}$. In spite of ergonomic recommendations, these professionals end up adopting vicious or wrong positions which, in the future, may impair their health, triggering cervical and lumbar disks degeneration and inflammatory processes in shoulders, elbows, wrists and hands $s^{8-11}$.

Musculoskeletal disorders are prevented by means of ergonomically organized environments, adequate working postures and intervals between consultations. Dental ergonomics looks at organizing environments to provide professionals with higher productivity allied to $\mathrm{QL}^{12,13}$. The posture of professionals and their working environment are in general organized according to standards proposed by the partnership between the International Standards Organization (ISO) and the Federation Dentaire Internacionale (FDI) which aims at optimizing dentists' work, promoting a restructuring to standardize dental office working routine by establishing ergonomic standards and guidelines ${ }^{14}$.

ISO, in 1980, has divided the dental office in 12 virtual parts, as the hands of a clock, the center of which is patient's oral cavity $^{12}$. Dental equipment is classified according to the disposition of its items, being classified as Type I, that is, the working unit is lateral to the professional; Type II, or posterior disposition; the side table is behind patient's head; Type III, with transthoracic positioning, which allows the dentist to work without assistants, preventing torsions to pick the tools to be used; and Type IV, or to the right side of the assistant.

Lack of physical activity and sedentary lifestyle also contribute to increase the risk of developing or worsening some medical conditions, such as cardiovascular and metabolic disorders and musculoskeletal pain ${ }^{15,16}$. Some North-American studies show that frequent exercises are associated to lack or less painful, depressive or anxiety symptoms $s^{16,17}$.

To promote health and minimize negative physical consequences of the profession, it is necessary to know the profile of professionals, their working environment and current health reality of dentists.

This is an epidemiologic study on the prevalence of musculoskeletal pain by ergonomically observing professionals during their clinical activity, both in the public and private sector.

\section{METHODS}

This is a transversal, descriptive, inquiry-type and observational study. Population was made up of dentists $(n=80)$ working in the public service (primary and secondary attention) and professionals of the private sector of a Brazilian city with approximately 200 thousand inhabitants. Sixtyseven dentists agreed to participate in the research. Exclusion criteria were individuals with some congenital or acquired physical disability involving upper or lower limbs, joints or spine; pregnant and breastfeeding women. People not agreeing to participate in the research or those not present during data collection days were not included in the study.

Research was carried out in two stages. First, dentists have answered a self-applicable questionnaire and then they were observed during dental assistance. A questionnaire was developed for the first stage to check the frequency of musculoskeletal pain and occupational injuries of dentists, the location of such pains, as well as to record labor activities, the existence or not of pauses or micro-pauses between assistances, the practice of physical activities and their frequency. For the second stage, a different data collection tool was developed based on the document "Adopting a healthy sitting working posture during patient treatment" 18 , integral part of ISO standardization 106/SC 6 N 411 of 2006, which describes ergonomic guidelines for dental assistance. As from this document, a list of ergonomic positions to be adopted during dental assistance was developed.

The observational stage was made up of 6 items: dentists position during treatment $(7 \mathrm{~h}, 9 \mathrm{~h}, 11 \mathrm{~h}$ or $12 \mathrm{~h})$; equipment (dental chair) and office furniture position; check whether they worked with the help of an assistant; spine, head and legs position. These items were taken into consideration during observation because studies show that inadequate posture, lack of pauses, poorly designed furniture and equipment, repeatability of movements, use of excessive strength, static posture for long periods, are primary causes of musculoskeletal pain and discomfort. When carrying out activities in the sitting position, there are two frequent arm movements: arm displacement to the front (flexion) and to the side (abduction). These movements are noxious when carried out above the shoulder line because they produce torque on rotating cuff equivalent to nine times the upper limb weight ${ }^{1}$.

Data were collected during six months. In the first contact 
with dentists, guidelines were given about the objectives of the study to get their consent to participate in the research by means of signing the Free and Informed Consent Term (FICT). Data were obtained by means of a questionnaire filled in a private location, in individual sessions, before they started their clinical activities, without impairing their rhythm. After this stage, dentists were observed during a working period to check their position while carrying out clinical procedures $(7 \mathrm{~h}, 9 \mathrm{~h}, 11 \mathrm{~h}$ or $12 \mathrm{~h}$ ); equipment (dental chair) and office furniture position; whether they worked with the help of an assistant; position of head and spine (not binding excessively to the front, laterally and rotations) and legs (maintenance of the angle between the thigh and the leg between 90 and 120 degrees).

After collection, data were analyzed by the programs Epi Info 7 and Bioestat $5.3^{19}$. Chi-square test was used to analyze the relationship between socio-demographic variables and the presence of pain and significance level was $5 \%$, or $\mathrm{p}<0.05$.

This study was approved by the Research Ethics Committee, in accordance to Resolution 466, from December 12, 2012 (Process FOA 373.186).

\section{RESULTS}

Total sample was made up of 67 dentists, of whom 25 (37.31\%) worked exclusively for the public sector, being most males (73.0\%), 35 (52.23\%) worked for the private sector and slightly more than half were females $(51.0 \%)$ and 7 $(10.44 \%)$ for both sectors; of these, $57.0 \%$ were males.

Most dentists worked 8 hours a day $(46.0 \%)$, being that $64.0 \%$ of them have stated having sporadic intervals between consultations. No professional reported doing any type of stretching.

All private sector professionals worked as generalists, although attending specialization courses in orthodontics and implantology. Most of these professionals have working loads above those of the public service, working for approximately 12 daily hours and have stated not having intervals between consultations $(70.0 \%)$, being that $74.0 \%$ seldom stretch themselves. From professionals stating being generalists, $11 \%$ worked both for the public and the private sector. Daily working hours of such professionals were $8 \mathrm{~h}(50.0 \%)$ and intervals between consultations were few $(86.0 \%) ; 84.0 \%$ have reported stretching arms and legs.

With regard to occupational pain/injury, $65.67 \%$ of dentists have reported some type of injury.

To identify specific characteristics of medical leaves of professionals participating in the research, it was observed that public service professionals had a higher number of leaves due to pain/injuries (64\%) as compared to dentists working for the private sector $(18 \%)$.

When relating pain to gender, there has been no statistically significant association, but the prevalence of pain was higher among female dentists (67.86\%).

The analysis of variables to identify the origin of pain was carried out by means of incorrect postures adopted during clinical assistance. With this, it was observed that many professionals would rotate their heads during consultations $(73.13 \%)$, their spine $(47.76 \%)$ and that the position of their legs was less than $90^{\circ}$ with regard to the floor during work (91.04\%).

Table 1 shows the position of equipment with regard to working environment, where most of them were placed in "Position I" with regard to the office $(53.73 \%)$. Most frequently adopted positions by professionals during work were $9 \mathrm{~h}$ (35.82\%) and $11 \mathrm{~h}(51.23 \%)$, positions which favor assisted work, carried out by $79.10 \%$ of professionals.

According to information given by dentists, most professionals (55.22\%) have reported practicing some physical activity, such as: body building, running/walking, Pilates or fights in general, keeping a frequency of 3 days a week (48.64\%) (Table 2).

Table 1. Frequency of dentists working place characteristics, according to professionals working sector. Araçatuba, 2012

\begin{tabular}{llcccccc}
\hline \multirow{2}{*}{ Variables } & & \multicolumn{2}{c}{ Public } & \multicolumn{2}{c}{ Private } & \multicolumn{2}{c}{ Both } \\
& & $\mathrm{n}$ & $\%$ & $\mathrm{n}$ & $\%$ & $\mathrm{n}$ & $\%$ \\
\hline Type of & Position I & 20 & 80 & 30 & 83.3 & 6 & 85.7 \\
equipment & Position II & 5 & 20 & 6 & 16.7 & 1 & 14.3 \\
& Total & 25 & 100 & 36 & 100 & 7 & 100 \\
W orking & 9 & 10 & 40 & 12 & 34.3 & 2 & 28.6 \\
position & 11 & 14 & 56 & 18 & 51.4 & 3 & 42.8 \\
(hours) & 12 & 1 & 4 & 5 & 14.3 & 2 & 28.6 \\
& Total & 25 & 100 & 35 & 100 & 7 & 100 \\
\hline
\end{tabular}

Table 2. Socio-demographic variables and factors preventing musculoskeletal diseases according to dentists working place. Araçatuba, 2012

\begin{tabular}{llcccccc}
\hline Variables & & \multicolumn{2}{c}{ Public } & \multicolumn{2}{c}{ Private } & \multicolumn{2}{c}{ Both } \\
& & $\mathrm{n}$ & $\%$ & $\mathrm{n}$ & $\%$ & $\mathrm{n}$ & $\%$ \\
\hline Gender & Male & 18 & 73 & 17 & 49 & 4 & 57 \\
& Female & 7 & 27 & 18 & 51 & 3 & 43 \\
& Total & 25 & 100 & 35 & 100 & 7 & 100 \\
Physical & Yes & 16 & 64 & 18 & 51.4 & 3 & 42.9 \\
activity & No & 9 & 36 & 16 & 45.7 & 4 & 57.1 \\
& NR & 0 & 0 & 1 & 2.9 & 0 & 0 \\
& Total & 25 & 100 & 34 & 100 & 7 & 100 \\
Type of & Body building & 10 & 45.4 & 10 & 41.6 & 2 & 33.4 \\
activity & Running & 4 & 18.1 & 5 & 20.8 & 1 & 16.7 \\
& Pilates & 2 & 9 & 1 & 4.1 & 1 & 16.7 \\
& Fights & 1 & 4.5 & 5 & 20.8 & 0 & 0 \\
& Other & 5 & 27.7 & 3 & 12.4 & 2 & 33.2 \\
& Total & 22 & 100 & 24 & 100 & 6 & 100 \\
Weekly & Two & 5 & 31.2 & 3 & 16.7 & 2 & 66.7 \\
frequency & Three & 7 & 43.7 & 10 & 55.5 & 1 & 33.3 \\
& Four or more & 4 & 25 & 5 & 27.8 & 0 & 0 \\
& Total & 16 & 100 & 18 & 100 & 3 & 100 \\
\hline \multirow{5}{*}{} & & & & & & Continue... \\
& & & & & &
\end{tabular}


Table 2. Socio-demographic variables and factors preventing musculoskeletal diseases according to dentists working place. Araçatuba, 2012 - continuation

\begin{tabular}{llcccccc}
\hline Variables & & \multicolumn{2}{c}{ Public } & \multicolumn{2}{c}{ Private } & \multicolumn{2}{c}{ Both } \\
& & $\mathrm{n}$ & $\%$ & $\mathrm{n}$ & $\%$ & $\mathrm{n}$ & $\%$ \\
\hline Professional & Yes & 13 & 81.2 & 18 & 66.7 & 4 & 80 \\
orientation & No & 3 & 18.8 & 9 & 33.3 & 1 & 20 \\
& Total & 16 & 100 & 27 & 100 & 5 & 100 \\
\multirow{3}{*}{$\begin{array}{l}\text { Type of } \\
\text { professional }\end{array}$} & Physiotherapist & 2 & 13.4 & 3 & 15.8 & 1 & 25 \\
& Physical educator & 13 & 86.6 & 16 & 84.2 & 3 & 75 \\
& Total & 15 & 100 & 19 & 100 & 4 & 100 \\
\hline
\end{tabular}

$\mathrm{NR}=$ no reply.

Most dentists practicing some physical activity did it with orientation of a qualified professional $(72.91 \%)$, such as physical educator $(84.21 \%)$ or physiotherapist $(15.79 \%)$.

\section{DISCUSSION}

Musculoskeletal injuries are increasingly becoming object of concern, research and discussion worldwide. It is critical for professional and personal QL of dentists to know their causes, manifestations, psychological aspects, how to prevent and treat such injuries ${ }^{20}$. Carrying out labor activities in static postures, or with few and low amplitude movements leads to the development of musculoskeletal disorders in several professions, and dental practice is a risk factor for the development of such disorders ${ }^{21}$.

In analyzing the presence of pain or occupational injury, $65.67 \%$ of dentists have reported having some type of injury. In activities where movements are cyclic, short and repetitive, added to static muscle contraction caused by poor posture, more than ergonomic solutions are needed. Musculoskeletal pain complaint by dentists has been described by several authors ${ }^{6,14,21,22}$, who state that pain reports are very common among dentists due to the time they spend sitting down or working in a same posture, which most of the time is not ergonomic.

Sometimes, to carry out a task, in a certain working place, people generate mechanical overload in their musculoskeletal structures even unconsciously, especially when they adopt inadequate occupational or functional postures as a function of poorly designed work places ${ }^{1}$. Not all studies on musculoskeletal pain in dentists describe specific or standardized criteria to accurately diagnose this and sometimes such criteria are inconsistent from one examiner to the other ${ }^{23,24}$.

Barbosa et al. ${ }^{25}$ have stressed that $68.9 \%$ of inquired professionals had pain complaints at the end of the working day, similar to what was found in this study where most dentists have stated not frequently pausing between consultations $(86 \%)$. Sometimes, the pause is limited to lunch time. According to Nunes, Freire \& Leles ${ }^{3}$, this attitude is linked to work market demand both in the public and private sectors, which increases the number of profession- als with pain. Resting pauses are not a vital body need, however the introduction of this practice in the daily life may decrease mental fatigue, especially for workers like dentists who require a lot from their nervous system, that is, in mental works where fingers agility and sense organs requirements are important ${ }^{1,21}$. It was also observed that the number of medical leaves caused by musculoskeletal disorders was high, especially among public sector professionals (64\%).

The presence of pain/injury related to dentists occupation was high in this study (65.67\%) and there has been higher prevalence of musculoskeletal pain among females $(67.86 \%)$, result also found in most literature studies $^{6,21,26,27}$. Female dentists and surgery specialists have more injury than males and any other specialty and such factor may be related to high strengths and continuous pressures occurring during such procedures ${ }^{23}$. Although there is no evident reason for musculoskeletal pain among females, there is a suggestion in these studies that females are more attentive to their health and wellbeing, go through several monthly hormonal changes or that they might have a lower pain threshold as compared to males, being less resistant to constant pain and daily stresses ${ }^{6,21,26,27}$.

Dentists participating in this study have reported that long working hours (59.70\%) and not maintaining working position $(40.30 \%)$ are items worsening pain at the end of the day. This fact was also pointed out by other studies with dentists ${ }^{6,22}$. When working hours go beyond the tolerance of the worker, that is, physical or mental workload, pause becomes a physiological mechanism to compensate and prevent muscle and mental fatigue. Micro-pauses are as important as regular labor exercises or long pauses, because they allow professionals to adopt some postures to decrease muscle stress without interrupting their work or during short intervals, such as drinking water, chatting or going to the restroom, between consultations. These short pauses release lactic acid built up by prolonged postures, improving tissue oxygenation ${ }^{1,6}$.

Dentistry forces professionals to use UULL and adjacent structures frequently with the same repetitive movement pattern due to their clinical activity. This may induce mechanical compression of structures such as hands and shoulders as a function of inadequate postures or excessive strength used for surgical techniques ${ }^{6}$.

These complaints are primarily related to neck, shoulders and cervical and lumbar spine pain, similar to those found in most studies ${ }^{1,21,22,26,28}$, stressing that poor posture-related health problems are still afflicting professionals, in spite of technological advances.

To consider professionals correctly positioned on the bench, they should sit symmetrically erect and most possible to the back, allowing the sternum bone to be slightly advanced and raised, abdominal muscles should be smoothly compressed and back should be supported by posterior hip bones ${ }^{12,18}$.

Primary dentists' difficulty is the accurate visualization of 
the surgical field, forgetting the right posture, excessively bending the neck, very often followed by its rotation. This study has observed many incorrect postures, both of spine $(47.76 \%)$ and neck $(73.13 \%)$ projecting them a lot to the front, laterally or performing rotations; and legs (91.04\%) being unable to maintain the angle between thigh and leg in an interval of 90 and 120 degrees; and association with musculoskeletal pain during and after procedures. Garbin et al. ${ }^{12}$ have observed that the reason for a poor posture may be associated to lack of knowledge about the right posture. Other studies associate working hours and excessive number of patients per period as influencing occupational pain ${ }^{6,21,22,29}$. Musculoskeletal injuries are appearing increasingly earlier during dentists professional life, indicating that they leave graduation courses with noxious postural habits ${ }^{27,30}$.

So, there is an international consensus that musculoskeletal injuries are causally related to labor activities with the presence of ergonomic stressors, such as: repetitive movements, vigorous efforts, non-neuter postures, vibrations or combinations of such exposures, stressing also that the lack of muscle strengthening and postural education cooperates for the installation of such pains/injuries ${ }^{21,24}$. Evidences of dentistry as a profession with potential risk for the development of musculoskeletal diseases are questionable, because studies to date have no standardization of methods ${ }^{23}$. Although our study has not shown statistically significant association or correlative potential for the variable lack of pain and the practice of physical exercises, it is important to stress that most professionals $(55.22 \%)$ have reported practicing some physical activity such as body building, running/walking, Pilates or fights in general, keeping a frequency of 3 times a week (48.64\%). Even so, there has been a high rate of labor-related pain complaint (65.67\%). There is a consensus in the literature that practicing regular physical activity oriented by a qualified professional (physical educator or physiotherapist) may prevent the installation of musculoskeletal pain or the worsening of chronic pain ${ }^{27,31,32}$.

Notwithstanding most professionals practicing some physical activity, the number of sedentary professionals was high $(44.78 \%)$. Sedentary life is recognized as an important factor for poor health and early death. So, a physical exercise program may contribute to minimize workload, to better tolerate postural stress and to protect from some manual work hazards in the case of dentists ${ }^{1,27,30-32}$. Daily exposure to aggressions of different origins and characteristics is a factor that, added to sedentary life, may negatively influence QL of people. So, the practice of physical exercises and pauses between consultations play a protective role for dentists ${ }^{1,27}$.

Musculoskeletal injuries in dentistry often start with postural fatigue of trunk and shoulders stabilizing muscles. Since there is fatigue of such muscles, dentists tend to adopt a poor posture, preparing their body for injuries. Professionals should carry out specific exercises to strengthen the trunk and the shoulder girdle to improve spinal health and integrity, maintain a good labor posture, optimizing the function of arms and hands, thus preventing injuries ${ }^{27,33}$. Our study had some limitations, such as refusal of professionals to participate, especially those working in the public sector, by fear of retaliation by their bosses. Professionals were not comfort being observed during assistance. It is worth mention also that data were collected by means of self-report questionnaires and so answers were subjectively measured. It might be that prospective studies with larger samples are needed to be able to delimit musculoskeletal pain among dentists in the future.

\section{CONCLUSION}

Dentists had a high prevalence of musculoskeletal pain which may be related to excessive working hours and to incorrect postures adopted during dental procedures. These factors may be worsened by the low frequency of physical exercises and lack of pauses and micro-pauses between consultations. Further studies on the subject would be interesting to explain the epidemiology of musculoskeletal pain in dentists, including the identification of risk factors and their impact on labor activity and quality of life.

\section{ACKNOWKEDGMENTS}

To the Foundation for Research Support of the state of São Paulo (FAPESP) for the financial support given during the study.

\section{REFERENCES}

1. Kotliarenko A, Michel-Crosato E, Biazevic MG, Crosato E, Silva PR. Distúrbios osteomusculares e fatores associados em cirurgióes dentistas do meio oeste do estado de Santa Catarina. Rev Odonto Cienc. 2009;24(2):173-9.

2. Carmo IC, Soares EA, Virtuoso Júnior JS, Guerra RO. Fatores associados à sintomatologia dolorosa e qualidade de vida em odontólogos da cidade de Teresina - PI. Rev Bras Epidemiol. 2011;14(1):141-50.

3. Nunes MF, Freire MC, Leles CR. Quality of life of public health service dental hygienists in Goiânia, Brazil. Int J Dent Hyg. 2008;6(1):19-24.

4. Bergman S. Public health perspective--how to improve the musculoskeletal health of the population. Best Pract Res Clin Rheumatol. 2007;21(1):191-204.

5. Hayes MJ, Taylor JA, Smith DR. Predictors of work-related musculoskeletal disorders among dental hygienists. Int J Dent Hyg. 2012;10(4):265-9.

6. Regis Filho GI, Michels G, Sell I. Lesōes por esforços repetitivos/distúrbios osteomusculares relacionados ao trabalho em cirurgióes-dentistas. Rev Bras Epidemiol. 2006;9(3):346-59.

7. Alexopoulos EC, Stathi IC, Charizani F. Prevalence of musculoskeletal disorders in dentists. BMC Musculoskelet Disord 2004;5(1):1-8.

8. Anton D, Rosecrance J, Merlino L, Cook T. Prevalence of musculoskeletal symptoms and carpal tunnel syndrome among dental hygienists. Am J Ind Med. 2002;42(3):248-57.

9. Horton SJ, Johnstone CL, Hutchinson CM, Taylor PA, Wade KJ. Clinical working postures os bachelor or oral health students. N Z Dent J. 2011;107(3):74-8.

10. Kumar SP, Kumar V, Baliga M. Work-related musculoskeletal disorders among dental profissionals: an evidence-based update. Indian J Den Educ. 2012;5(1):5-12.

11. Ayers KM, Thomson WM, Newton JT, Morgaine KC, Rich AM. Self-reported occupational health of general dental practitioners. Occup Med. 2009;59(3):142-8.

12. Garbin AJ, Garbin CA, Diniz DG, Yarid SD. Dental students' knowledge of ergonomic postural requirements and their application during clinical care. Eur J Dent Educ. 2011;15(1):31-5.

13. Borges AB, Pucci CR, Torres CR, Barcellos DC. Evaluation of the occupational health program applied the students of dentistry. Braz Dent Sci. 2009;12(4):59-63.

14. Garbin AJ, Garbin CA, Diniz DG. Normas e diretrizes ergonômicas em odontologia: o caminho para a adoçáo de uma postura de trabalho saudável. Rev Odontol Univ Cid São Paulo. 2009;21(2):155-61. 
15. Maron BJ. The paradox of exercise. N Engl J Med. 2000;343(19):1409-11.

16. Boscolo RA, Esteves AM, Mello MT, Tufik S. O exercício físico e os aspectos psicobiológicos. Rev Bras Med Esporte. 2005;11(3):203-7.

17. Silva RS, Silva I, Silva RA, Souza L, Tomasi E. Atividade física e qualidade de vida. Ciência Saude Coletiva. 2010;15(1):115-20.

18. Ergonomics in dentistry, Part 1. Dent Today. 2002;21(4):98-103.

19. CDC. EpiInfoTM, a database and statistics program for public health professionals [computer program]. Atlanta: Centers for Disease Control and Prevention; 2007. http://wwwn.cdc.gov/epiinfo/

20. Orso PJ, Murofuse NT, Matias LV, Marziale MH. Reflexôes a cerca das lesôes por esforços repetitivos e a organizaçáo do trabalho. Rev Online Bibl Prof Joel Martins. 2001;2(2):47-58.

21. Hayes MJ, Smith DR, Taylor JA. Musculoskeletal disorders and symptom severity among Australian dental hygienists. BMC Res Notes. 2013;6:250.

22. Alexandre PC, da Silva IC, de Souza LM, de Magalhães Câmara V, Palácios M, Meyer A. Musculoskeletal disorders among Brazilian dentists. Arch Environ Occup Health. 2011;66(4):231-5.

23. Garbin AJ, Garbin CA, Moimaz SA, Baldan RC, Zina LG. Dental practice and musculoskeletal disorders association: a look at the evidence. Arch Environ Occup Health. 2011;66(1):26-33.

24. Punnett L, Wegman DH. Work-related musculoskeletal disorders: the epidemiologic evidence and the debate. J Electromyogr Kinesiol. 2004;14(1):13-23.

25. Barbosa EC, Souza FM, Cavalcanti AL, Lucas RS. Prevalência de distúrbios osteomus- culares relacionados ao trabalho de cirurgiôes-dentistas de Campina Grande-PB. Pesq Bras Odontoped Clin Integr. 2004;4(1):19-24.

26. Moimaz SA, Saliba NA, Blanco MR. [The women workforce in dentistry in Araçatuba - SP]. J Appl Oral Sci. 2003;11(4):301-5. Portuguese.

27. Yi J, Hu X, Yan B, Zheng W, Li Y, Zhao Z. High and specialty-related musculoskeletal disorders afflict dental professionals even since early training years. J Appl Oral Sci. 2013;21(4):376-82.

28. Augustson TE, Morken T. [Musculoskeletal problems among dental health personnel. A survey of the public dental health services in Hordaland]. Tidsskr Nor Laegeforen. 1996;116(23):2776-80. Norwegian.

29. Al Wazzan KA, Almas K, Al Shethri SE, Al-Qahtani MQ. Back \& neck problems among dentists and dental auxiliaries. J Contemp Dent Pract. 2001;2(3):17-30.

30. Abreu MH, Lopes-Terra MC, Braz LF, Rímulo AL, Paiva SM, Pordeus IA. Attitudes and behavior of dental students concerning infection control rules: a study with a $10-$ year interval. Braz Dent J. 2009;20(3):221-5.

31. Toscanos JJ, Egypto EP. A influência do sedentarismo na prevalência de lombalgia. Rev Bras Med Esporte. 2001;7(4):132-7.

32. Souza JB. Poderia a atividade física induzir analgesia em pacientes com dor crônica? Rev Bras Med Esporte. 2009;15(2):145-50.

33. Valachi B, Valachi K. Preventing musculoskeletal disorders in clinical dentistry. Strategies to address the mechanisms leading to musculoskeletal disorders. J Am Dent Assoc. $2003 ; 134(12): 1604-12$. 